the house, by which a tobaceo cataplasm conld be quickly madc; hence it instantly camc into mind that he might swallow tobacco smokc as a substitute. He was furnished with a cigar and desired to make vehement efforts to pass the smoke into his stomach. He soon became sick and puked, his whole frame relased, and covered with a cold sweal. Tlee bowel was now very easily reduced and the free use of volatile spirits both internally and externally, soon restored him.

Whether this method of using tobacco has generally any advantage over the enema, I am not prepared to say. With women, and with those men too, who are delicate with respect to these obsecne operations, it may be preferred, for delicacy ought al ways to be carefully regarded. I have very frequently used it since for spasms in the bowels, and for hernia; but it has screral times entirely failed, owing, as I supposed, to the patient's inability to pass a sufficient quantity into the stomach. Those, moreover, who are unfortunatcly, or, let us say, viciously accustomed to the use of this poison, arc not to be orercome by a small quantity. That smoke can be passed into the stomach by deglutition, I am very certain from my own personal experi-
ments.

Strangulated hernia was of frequent occurrence in my busy and extensive practice, but of all the numerous cases that occurred to me during twentyfive ycars in Northumberland and its vicinity, every case was successfully reduced. I have performed the operation in three cases only, and these were in the practice of other physicians; one was suceessful and two were lost by previous sphacelation and a subsequent arificial anus. This suecess with the taxis, I impute entirely to the prompt and powerful aid of tobacco. If it be objected, that it is a dangerous remedy and that a few patients have been destroyed by it, we reply, that either the discase or the operation is far more to be dreaded than the usc of tobacco in careful liands. The scientific physician will consider the strength and idiosyncrasies of his patient, and use the medicine with prodence. When I contrast this with the ignorant temerity with which the nurses and busybodies have often used this article to my knowledge, without measure and yet without detriment, I am fully persuaded that in the hands of skilful, scientific physicians, it ought not to be considered as a dangerous remedy.

\title{
ArT. VI. Case of Serious Injury of the Knee Joint, Terminating in the almost Perfect Recovery of the Use of the Limb. By Darwiv. E.
}

Thoras Coffee, xtat. 18, on the 18th day of May last, whilst engaged in pointing rails with an ase, in consequence of the axe glancing from the 
rail, received a scvere cut on the outside of the right knee joint. The incision was horizontal inclining inwards and downward, from within a quarter of an inch of the patella, two inches posteriorly, and was of a somewhat conical sliape; that is, the opening in the sac was not quite so large as the incision through the skin, in eonsequence of being made by the hecl of the ase, which would necessarily give it the above mentioned shape.

The direetion and force of the axe was such, that in passing inwards, it chipped of a portion of the external surface of the femoral condyle, logether with a portion of its articulating surfacc. 'The edge of the instrument then sank through the external semilunar cartilage, into the hcad of the tibia, slightly splintering the head of that bone, a litile anterior to the head of the fibula. 'The wound blcd freely at first, but the henorrhage soon ccascd. The limb was lying in an extended position, but whilst I was engaged in dressing the wound, the paticnt, by some inadvertence, caused it to slip from its support and become suddenly flcxed. At this moment, the joint admitted a large quantity of air, which entered with a loud gurgling sound. This I considered as immineutly increasing the danger of the patient. I immediately placed the limb in an extended position, and by compression with my fingers forced a considerable portion of the air, together with some coagulum from the cavity, and by placing the wound in a depending posilion and passing my finger into the cavity of the joint, I succeded in breaking up and removing large portions of coagulum which yet remained.

After this was effected and the cavity perfectly freed from all extraneous substances, such as bits of bone, \&c., a ficxible catheter attached to a syringe was inserted, by the suction power of which the remaining air was removed; the catheter was then very carcfully abstraeted anu the wound firmly closed by adhesire straps.

The whole limb to the pelvis was then enveloped in a roller, the knee being padded beneath the roller with cotton batting that the pressure might be distributed around the joint crenly. The patient was then placed in bed and the wounded limb secured to an inelined plane, so that the foot was considerably elevated, in which position he rested comfortably.

$19 t h$. Comfortable with the exeeption of slight headache and a litte soreness in wound. Upon removing the roller and examining the knee, no swelling had taken place. Diet $4 \mathrm{oz}$. boiled milk and two ounces bread, twice a day. To be purged with salis.

20th. Some headache; tongue white; some pain in the knee. Complaioed of tiglitness of the roller about the knee and of soreness of the wound. Upon'remoring the roller, the joint was observed to be considerably swollen, with tenderness at a point opposite to the wound over the internal condyle. R. scarificd cups, no. ij, over internal condyle. The knee to be kept cool by the repeated application of cold water, and in the evening a large blister, so as to completely envelope the joint, over this the roller. Diet same. To be purged with salts. 


\section{Stanton's Case of Serious Injury of the Knee Joint.}

21st. Blister had drawn well and discharged frecly; strelling increased; knee quite painful; headache; tongue white. Diet, rice soup. To bc purged freely with salts.

On the 25th the blister was again applicd, and from this time the patient continued to do well. To the $3 \mathrm{~d}$ day of June the patient remained in bed with the limb elevated. $O_{x}$ this day he walked about the room, and from that time continued to perform gentle motions of the joint every day, until the nearly perfect use of it was restored to him. Aftcr the 25th of May, the ouly treatment was pnrging daily with salts, and the constant application of the roller, the joint as before mentioned being padded with cotton.

The wound did well, with the exception of a few prolific granulations, which were easily subdued with burnt alum.

The only difficulty he now experiences in the use of the limb, is when he ascends a staircase quickly, and when, as he expresses il, "he squats down on his hunkers." In ordinary walking and running, lie lias the per-
fect use of the limb.

The peculiarity of this case, is the happy termination of it after so serious an injury. When we consider that even the most trivial injuries of this joint are apt to terminate unpleasantly, and sometimes fatally, and how timid the most skilful surgeons are about the most trifling operations upon this joint, this case is rendered tbe more remarkable.

The fact that the knee joint should be laid completely open-a portion of the articulating surface removed-the semilunar cartilage divided and the whole synovial surface exposed to the action of the atmospheric air-the interesting and pleasant cases with which it is sometimes the lot of the sur-
geon to meet.

Holliday's Cove, Brooke Co. Va., December 6, 1839.

Note by the Editor.

vested will much interest fry justly considered the preceding case as inhaving been restored after from the circnmstance of the use of the limb sions which he entertained, severe an injury to a joint. The apprehenpatient from the entrance of opinions of most surgeons, we into the wonnd, tbough sustained by the Monro, that air, is an active irritant to the olly unfonnded. It was taught by trine has since been pretly generally the synovial membranes; and this docsnfficient examination, and in positive experiments, so far as position to some well-determined facts. No diction; but clinical observations know, can, it is true, be cited in contraVery severe symptoms undoubtedly, of afford no evidence in its support. the air; but may not these with ly, often arise from exposure of a joint to stances which atlend the injury, the propriety be referred to the circum- 
ment, \&c., than to any irritating properties of the air? In favour of this view many cxamples might be adduced. Dr. Bond relates a ease in which " the putella was cut across transversely by a blow of an axe, and divided into two nearly equal portions, so that the joint was laid open," and Dr. B. " had a direet vicw into it. The paticnt was a healthy boy, aged eight years, and the fragments of the bone united without any apparent affection of the synovial membrane." (Philadclphia Journ. Med. \&. Phys. Sci. Vol. II. p. 273.) Other instanees in which joints have been freely opened without any bad symptoms accruing might be eited; whilst on the contrary the most violent effects lave ofien resulted from injuries of joints in which the wound was too small to admit the passage of air. It thus appears that the possession, by this fluid of any property by which it is enabled to exeite irritation in synovial membranes, remains as yet to be proved; though it is not to be denied, that a current of air may prove injurious to these membranes by its temperature, when this last is different from that of the tissue; or by absorbing the moisture of the parts, and thus placing them in an unnatural condition. But we have discussed the subject of the action of air on the different tissues so fully elscwherc, (sce American Cyclopedia of Practical Medicine and Surgery, vol. I. p. 263-270,) that we necd not enter into further details here.

Art. VII.-Remarks on the Climale, Population, Diseases, \&.c., of Malta, with an account of the Asiatic Cholera as it occurred in that Island and Gozo, in the summer of 1837. By Plivy EarLe, M. D., of Philadclphia.

Tre island of Malta, the ancient Melita, situated between the southern cxtremity of Italy and the African coast, is in latitude $35^{\circ} 50^{\prime}$ north, and in longitnde $14^{\circ} 15^{\prime}$ east. Its length is twenty miles, its greatest breadth twelve miles, and its surface, on the supposition hat it werc a perfect ellipse, 188 square miles. Its soil lies upon a continuous bed of limestone, which is soft in texture, light in colour, and far from being durable as a material for building, soon crumbling when cxposed to the elements. The southern coast, throughout nearly its whole extent, is inaccessible, tho rocks rising, in nearly perpendicular cliffs, to a licight, in somo places, of 300 feet. The soil, though neither ricls nor deep, is in a state of the highest eultivation, and, under the auspices of a nild climate, furnishes to the cultivator two crops in the year. The number of speeies of native plants, according to Dr. Zerafa, is 614; but it is thought that, were a perfect list made, it would amount to 700 . Many of the spccies are papilionaceons; but few of them belong to the labiata. 